\title{
Evaluating temperature thresholds and optimizing sowing dates of wheat in Bihar
}

\author{
ABDUS SATTAR ${ }^{1}$, GULAB SINGH ${ }^{1}$, SHRUTI V. SINGH ${ }^{1}$, MAHESH KUMAR ${ }^{2}$, P. VIJAYA KUMAR ${ }^{3}$ \\ and S.K. BAL ${ }^{3}$ \\ ${ }^{1}$ Agrometeorology Division, Centre for Advance Studies on Climate Change, \\ ${ }^{2}$ Department of Statistics and Mathematics, Dr. Rajendra Prasad Central Agricultural University, Pusa, Bihar \\ ${ }^{3}$ ICAR-Central Research Institute for Dryland Agriculture, Hyderabad-500 059, India \\ Corresponding author's email: sattar.met@gmail.com
}

\begin{abstract}
Studies on wheat-weather relationship were carried out at Pusa $\left(25.98^{\circ} \mathrm{N}, 85.67^{\circ} \mathrm{E}, 52 \mathrm{~m}\right)$, Bihar situated in middle Gangetic plains of India, with three popular wheat cultivars viz. RW 3711, HD 2824 and HD273, grown under five fixed dates of sowing viz. 15 November, 25 November, 5 December, 15 December and 25 December, for five consecutive rabi seasons from 2011-12 to 2015-16. Thresholds of maximum temperature $\left(T_{\text {max }}\right)$, minimum temperature $\left(T_{\min }\right)$ and bright sunshine hours $(B S H)$, associated with higher productivity, occurring at different phenophases, were determined. Results revealed that temperature played a crucial role in achieving higher grain yield of wheat. Both $T_{\max }$ and $T_{\min }$ during flowering to milking and flowering to maturity phases increased with delayed sowing dates beyond 25 November with consequent reductions in grain yield. During $50 \%$ flowering to milk stage, $T_{\max }$ and $T_{\min }$ above $24.6{ }^{\circ} \mathrm{C}$ and $11.6{ }^{\circ} \mathrm{C}$, respectively, reduced grain yield below $4000 \mathrm{~kg} \mathrm{ha}^{-1}$; significant reduction in grain yield was also noted beyond maximum temperature of $26.9{ }^{\circ} \mathrm{C}$. During flowering to milk and flowering to maturity phases, $T_{\max }$ and $T_{\min }$ exhibited highly significant negative correlation with grain yield, indicating higher temperatures causing lower grain yield. With delayed sowing, sensitive phases of the crop experienced higher air temperatures which led to reduction in grain yield. An increase of $T_{\max }$ from 29.2 to $32.1^{\circ} \mathrm{C}$ during flowering to maturity phases reduced the wheat productivity drastically in this region of Indo-Gangetic plains. Grain yield declined by $399 \mathrm{~kg} \mathrm{ha}^{-1}$ per $1{ }^{\circ} \mathrm{C}$ rise in $\mathrm{T}_{\max }$ during $50 \%$ flowering to maturity stage. Considering grain yield vis-à-vis temperature regimes during flowering to maturity stage, the most important recommendation for the farmers of the region would be to finish wheat sowing before 25 November in order to enable them to escape terminal heat stress in wheat and thereby realizing higher grain yield. The anthesis-time management by manipulating sowing dates could be a realistic adaptation strategy for attaining optimum grain yield under changing climate scenario.
\end{abstract}

Key words: Wheat, phenophase, grain yield, temperature, sunshine, heat stress.

Every crop/cultivar under a crop has its own optimal requirements of climatic variables viz. temperature, sunshine hours, rainfall etc. for attaining potential yield. The responses and requirements of these variables determine the growth and development of a plant in a given environment. Wheat is the most important winter crop in India occupying an area of over 30 million ha with a production of 94 million tonnes (DES, 2017). India ranks second after China in terms of wheat production with about $12 \%$ share in global wheat production. It is an important component crop in the ricewheat cropping system, which is widely followed by the farmers of Gangetic plains of India. It is grown all over IndoGangetic plains mainly as an irrigated crop. Of late, the vulnerability of growing wheat in this region of middle Gangetic Plains (eg., Bihar state) has increased owing to the problem of higher heat stress occurring late (during end of February to March) in the growing season (Anon, 2009; Sattar et al., 2014). Terminal heat stress is a serious climatic constraint for successful wheat cultivation in India, particularly when it occurs during grain filling stage (Sandhu et al., 2016; Chatrath et al., 2007). According to Joshi et al. (2007), $13 \cdot 5$ million ha of wheat area in India experiences heat stress (Vijaya Kumar et al., 2015). Pre-anthesis and post-anthesis occurrence of high temperatures and heat tend to make significant impact upon growth and photosynthetic efficiency of wheat crop (Wang et al., 2011). Heat stress affects photosynthetic efficiency with concomitant reduction in dry matter accumulation and grain yield (Farooq et al., 2011).

The effect of temperature on wheat productivity can 
be evaluated through imposition of different planting dates (Nahar et al., 2010; Ottman et al., 2012, Vijaya Kumar et al., 2015) and through regression of yield with weather parameters (Bal et al., 2004; Landau et al., 1988; Lobell et $a l ., 2005)$. Planting a crop on different dates during a year exposes the crop to different temperature regimes during its growing season, allowing an understanding of crop responses to temperature without the artificial conditions imposed by controlled environments (Vijaya Kumar, 2015). Crop responses to temperature regime vary with variety and phenological stage of the crop (Shpiler and Blum, 1986). With the help of crop weather relationship, it is possible to show as to how the changes in temperatures and solar radiation during different growth stages influence the crop productivity (Bal et al., 2018). The growth and yield of crops is dependent upon the integrated effects of weather phenomena prevailing during different growth stages. Understanding the thresholds of weather variables and their interactions with crop phenology and yield is the key to enhancing crop production (Sattar et al., 2017). Among the climatic factors, temperature plays a key role in determining the sowing time and consequently the duration of different phenophases, which ultimately affect the crop productivity (Tewari and Singh, 1993). High temperature stress is an important yield-limiting factor for wheat (Triticum aestivum L.) in most of the wheat growing areas of the world (Prasad et al., 2008). Many workers have identified cardinal temperatures for various physiological processes and growth stages of wheat (Porter and Gawith, 1999) and for optimum yield during some pheno-phases (Faroooq et al., 2011; Vijaya Kumar et al., 2013). But, information on temperature thresholds as well as the impact of temperature during critical growth stages on wheat yield in this region of middle Indo-Gangetic plains is rarely available. Hence, understanding the dynamics of temperature variability during critical growth stages $v i s-\grave{a}-v i s$ its effect on grain yield is an essential prerequisite for obtaining optimum productivity under changing climatic scenario. In view of this, an attempt has been made in this paper to assess the impact of weather variables on grain yield of wheat and also to evaluate the suitability of early planting and identify the thresholds of temperatures for maximizing its productivity.

\section{MATERIALS AND METHODS}

To evaluate the effect of temperatures on grain yield of wheat, three dominant cultivars of the region, viz. RW3711, HD2824 and HD2733 were grown at Research Farm of Dr. Rajendra Prasad Central Agricultural University, Pusa (25.98 ${ }^{\circ} \mathrm{N}, 85.67^{\circ} \mathrm{E}, 52 \mathrm{~m}$ ), Bihar during five consecutive rabi (winter) seasons from 2011-12 to 2015-16 with five fixed dates of sowing, viz. 15 November, 25 November, 05 December, 15 December and 25 December covering the entire period of sowing window, which is widely followed by the farmers of the region for sowing of wheat. The field experiment was laid out in Randomized Complete Block Design with three replications. The crop was raised following recommended package of practices for the area under irrigated conditions by applying fertilizer (nitrogenphosphorus-potassium at 120-60-40 $\mathrm{kg} \mathrm{ha}^{-1}$ ) to ensure unlimited nutrient and water supply. All P and K and a half dose of $\mathrm{N}$ were applied at sowing as basal dose. The remaining half dose of $\mathrm{N}$ was top dressed in two equal splits at crown root initiation and boot stages. The crop was kept weed free throughout the growing season. No pesticide was applied during the growing period as there was no infestation of insect-pests. The occurrence of phenological events like tillering, flowering, milk, dough and maturity in Julian day were recorded from each plot and average dates of these phases were calculated over the years and used for analysis. For categorization of yield of all treatments, four yield levels viz. yield $<2000 \mathrm{~kg} \mathrm{ha}^{-1}$, yield $>2000 \mathrm{~kg} \mathrm{ha}^{-1}$ and $<3000 \mathrm{~kg}$ $\mathrm{ha}^{-1}$, yield $>3000 \mathrm{~kg} \mathrm{ha}^{-1}$ and $<4000 \mathrm{~kg} \mathrm{ha}^{-1}$ and yield $>4000$ $\mathrm{kg} \mathrm{ha}^{-1}$ were selected for crop weather analysis. These categorizations were based on the spread of yield data over the experimental periods and local classification of wheat productivity realized in farmers' fields referred as very low, medium, moderately high and high. Phenophase-wise maximum and minimum temperatures were averaged over the crop seasons under each category of yield. Daily weather data on maximum and minimum temperatures, and bright sunshine hours for the growing season were collected from the nearby Agrometeorological Observatory, Dr. Rajendra Prasad Central Agricultural University, Pusa, Bihar. Based on daily weather observations, optimum weather conditions in terms of maximum temperature $\left(\mathrm{T}_{\max }\right)$, minimum temperature $\left(\mathrm{T}_{\text {min }}\right)$, mean temperature $\left(\mathrm{T}_{\text {mean }}\right)$, and bright sunshine hours (BSH) during different growth phases of wheat were worked out. Linear regression equations were attempted between grain yields and maximum temperature, minimum temperature and mean temperature to assess the rate of decrease of yield with increasing temperature. The slope values of regression were taken as rates of decrease of yield due to increase in temperatures in different phenological phases. Simple correlation coefficients between wheat grain yield and weather parameters were computed (Gomez and Gomez, 1976). The best-fit regression equations involving wheat yield and weather parameters occurring at different phases of growth were developed (Draper and Smith, 1966) to examine the wheat- weather relationship and to explore the climatic suitability of advancing wheat planting in order to 
avoid terminal heat stress during reproductive and maturity phases of the crop.

\section{RESULTS AND DISCUSSION}

\section{Optimum thermal environment and wheat productivity}

The experimental yields were categorized into different yield categories and for each category, thresholds of maximum and minimum temperatures have been worked out. Critical thresholds of maximum and minimum temperatures during different phenological stages of wheat required for realization of different yield levels have been identified (Table 1). Both maximum and minimum temperatures played significant role in influencing wheat yield. Maximum temperatures above 30.2 and $33.1{ }^{\circ} \mathrm{C}$ during $50 \%$ flowering to milk and $50 \%$ flowering to maturity stages, respectively, reduced grain yield to below $2000 \mathrm{~kg} \mathrm{ha}^{-1}$. Similarly, minimum temperature of 16.8 and $18.0{ }^{\circ} \mathrm{C}$ during $50 \%$ flowering to milk and $50 \%$ flowering to maturity, respectively, had deleterious effect on grain yield. As the region is known for prevalence of dry westerly wind during the flowering to maturity period of wheat crop, maximum temperature tends to increase in these stages resulting in non- setting of wheat grains. Lin et al. (1997) reported that floral sterility may limit the sink size due to increased temperature. The temperature rise during crop growth cycle might result in seed abortion and reduced grain yield (IPCC, 2001). Maximum temperature above $25^{\circ} \mathrm{C}$ caused reduction in grain yield below $4000 \mathrm{~kg}$ ha $^{-1}$ during $50 \%$ flowering to milking stage. At $50 \%$ flowering to maturitystage, maximum and minimum temperatures should be less than 29.2 and $14.4{ }^{\circ} \mathrm{C}$, respectively, for attaining grain yield above $4000 \mathrm{~kg} \mathrm{ha}^{-1}$. An increase in maximum temperature from 29.2 to $33.1{ }^{\circ} \mathrm{C}$ during flowering to maturity stage reduced wheat yield from the highest level of $>4000$ $\mathrm{kg} \mathrm{ha}^{-1}$ to the lowest level of $<2000 \mathrm{~kg} \mathrm{ha}^{-1}$. Shortening of the period of grain filling in wheat (Wheeler et al., 1996) might be the reason for low productivity under high temperature (Wang, 2012). The observation of Wheeler et al. (2000) that a few days of temperature above a threshold value, if coincident with anthesis, can significantly reduce yield by affecting subsequent reproductive processes also corroborated the results of the present study. You et al. (2009) observed significant reduction in wheat yield due to rise in temperature and it was $3-10$ per cent reduction with $1.8^{\circ} \mathrm{C}$ rise in temperature.

\section{Influence of temperature on grain yield}

The regression equations involving maximum, minimum and mean temperatures during $50 \%$ flowering to physiological maturity and grain yield were established (Figs. 1-4). Maximum temperature during $50 \%$ flowering to maturity phase showed negative linear relationship with grain yield, with coefficient of determination $\left(\mathrm{R}^{2}\right)$ of 0.527 being significant at $1 \%$ level of significance and accounting for $52.7 \%$ of the total variation in grain yield. Grain yield was found to be higher when maximum temperature was 27 to $28{ }^{\circ} \mathrm{C}$ during $50 \%$ flowering to maturity. Due to rise in maximum temperature by $1{ }^{\circ} \mathrm{C}$ during $50 \%$ flowering to physiological maturity, there was a reduction in grain yield by $399 \mathrm{~kg} \mathrm{ha}^{-1}$ (Fig. 1). Further, maximum temperature at 50 $\%$ flowering to milk stage also displayed negative linear relationship with grain yield, with $\mathrm{R}^{2}$ of 0.584 , being significant at $1 \%$ level of significance and explaining 58.4 $\%$ of the total variation in grain yield. Grain yield decreased by $279 \mathrm{~kg} \mathrm{ha}^{-1}$ due to $1{ }^{\circ} \mathrm{C}$ rise in maximum temperature during $50 \%$ flowering to milk stage. Maximum grain yield was obtained when maximum temperature of 21 to $22{ }^{\circ} \mathrm{C}$ prevailed during $50 \%$ flowering to milk stage (Fig. 2). On the other hand, mean temperature at $50 \%$ flowering to maturity phase demonstrated polynomial relationship with grain yield, with $\mathrm{R}^{2}$ of 0.63 being significant at $1 \%$ level of significance and explaining $63.0 \%$ of the total variation in grain yield. Maximum grain yield was obtained when mean temperature of 19 to $20^{\circ} \mathrm{C}$ prevailed during $50 \%$ flowering to maturity stage (Fig. 3). Moreover, minimum temperature prevailing during $50 \%$ flowering to maturity stage also showed polynomial relationship with grain yield, with $\mathrm{R}^{2}$ of 0.652 being significant at $1 \%$ level of significance and explaining $65.2 \%$ of the total variation in grain yield. Maximum grain yield was obtained when minimum temperature of 11 to 12 ${ }^{\circ} \mathrm{C}$ occurred during $50 \%$ flowering to maturity stage. There was a consistent reduction in grain yield at temperatures exceeding $12{ }^{\circ} \mathrm{C}$ during $50 \%$ flowering to maturity stage (Fig. 4). These results are in agreement with those reported by Hays et al. (2007) who observed that increased temperature restricted growth and productivity, particularly during reproductive crop stages. Lobell and Field (2007) recorded 0.6 to $8.9 \%$ reduction in grain yield of wheat for $1{ }^{\circ} \mathrm{C}$ rise in temperature.

Correlation coefficients involving weather variables and grain yield (Table 2) revealed that $\mathrm{T}_{\max }, \mathrm{T}_{\min }$ and $\mathrm{BSH}$ during the period from sowing to tillering showed positive correlation with grain yield. In contrast, $\mathrm{T}_{\max }, \mathrm{T}_{\min }$ and $\mathrm{BSH}$ occurring during $50 \%$ flowering to milking and $50 \%$ flowering to maturity phases demonstrated negative correlation with grain yield. When prevailed during sowing to tiller initiation stage, $\mathrm{T}_{\min }$ and $\mathrm{BSH}$ showed significant 


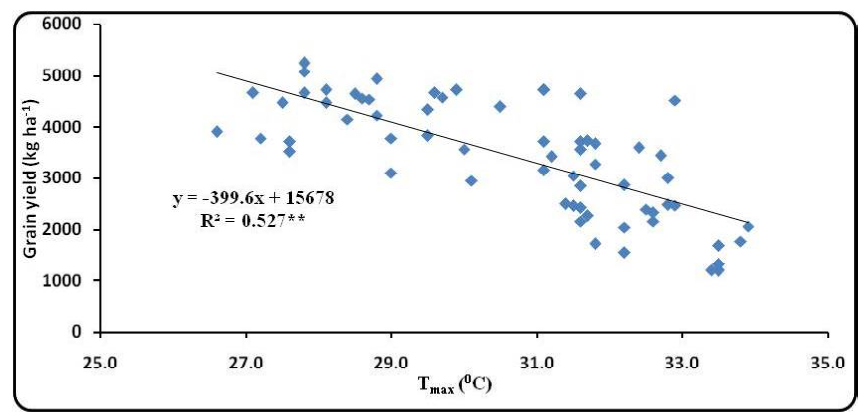

Fig.1: Relationship between grain yield and $\mathrm{T}_{\text {max }}$ during $50 \%$ flowering to maturity stage of wheat

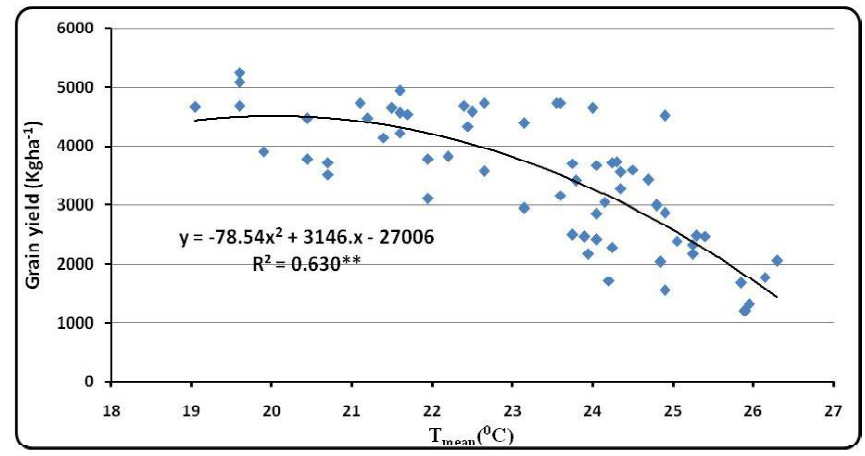

Fig. 3: Relationship between grain yield and $\mathrm{T}_{\text {mean }}$ during $50 \%$ flowering to maturity stage of wheat

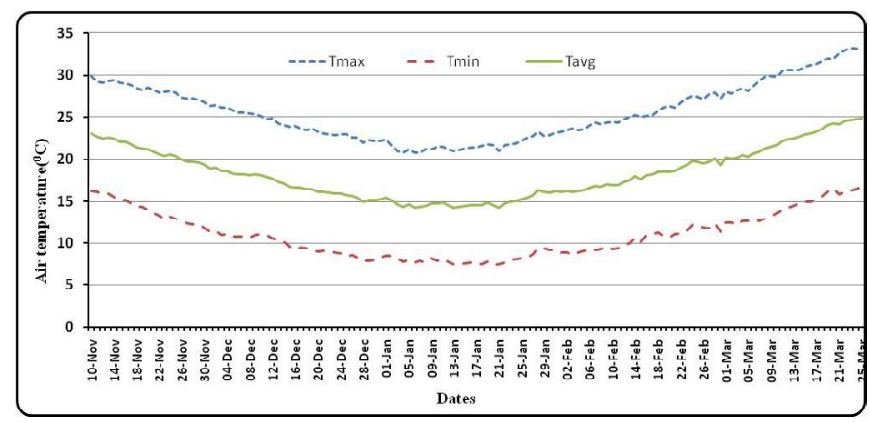

Fig. 5: Variation in daily normal maximum tempearture $\left(\mathrm{T}_{\max }\right)$, normal minimum temperature $\left(\mathrm{T}_{\min }\right)$ and average temperature $\left(\mathrm{T}_{\text {avg }}\right)$ during wheat growing season

positive correlation with grain yield, whereas when occurred during $50 \%$ flowering to milking and $50 \%$ flowering to maturity phases, $\mathrm{T}_{\max }$ and $\mathrm{T}_{\text {min }}$ exhibited significant negative correlation with grain yield. During sowing to tiller initiation period, higher values of $\mathrm{T}_{\max }, \mathrm{T}_{\min }$ and $\mathrm{T}_{\text {mean }}$ (Fig.5) as experienced by the early sown crops augmented greater initial growth which in turn led to higher grain production. To the contrary, higher values of temperatures (Fig. 6) occurring during $50 \%$ flowering to milk and $50 \%$ flowering to maturity phases reduced the growth of late sown crops

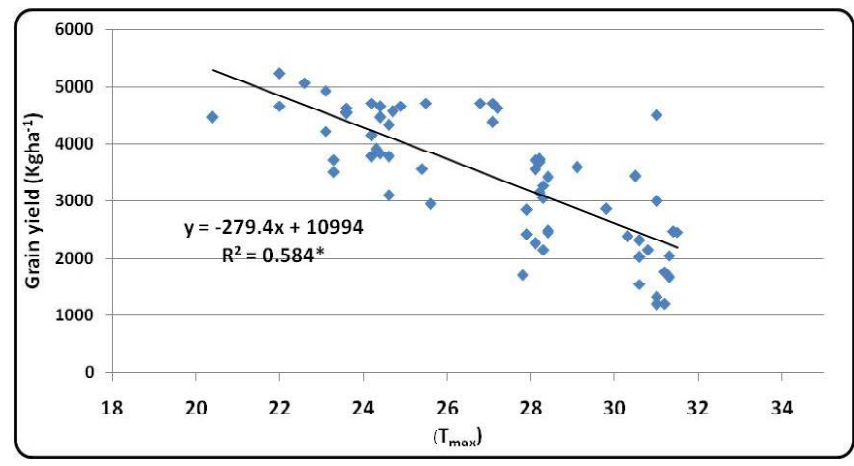

Fig. 2: Relationship between grain yield and $\mathrm{T}_{\text {max }}$ during $50 \%$ flowering to milk stage of wheat

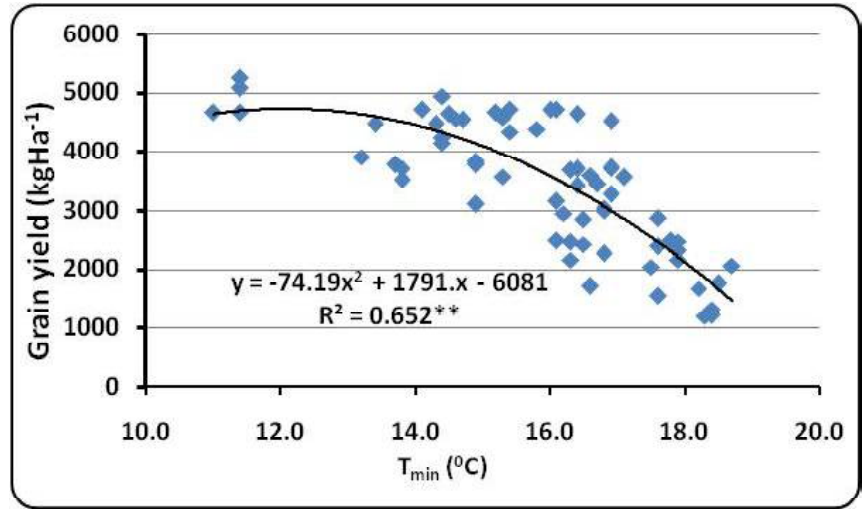

Fig.4: Relationship between grain yield and $\mathrm{T}_{\text {min }}$ during $50 \%$ flowering to maturity stage of wheat

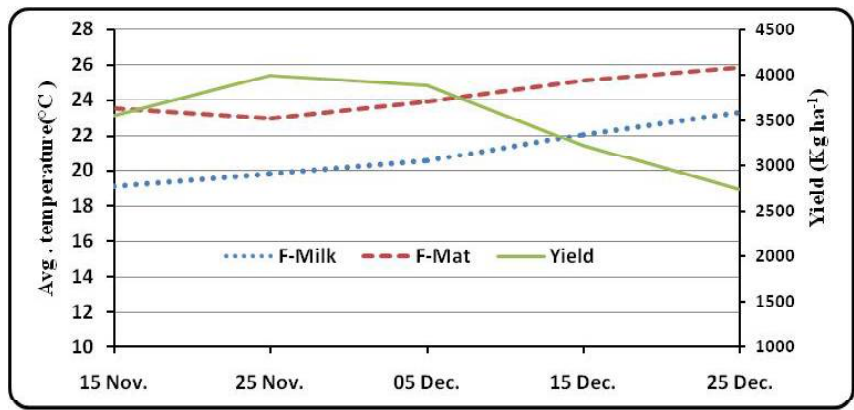

Fig. 6: Relationship of average air temperatures during flowering to milking (F-Milk) and flowering to maturity (F-Mat) stages with grain yield of wheat planted on different dates.

and produced lesser grain yield. Bapuji Rao et al. (2015) observed that an exposure to minimum temperature exceeding $12^{\circ} \mathrm{C}$ for 6 days and maximum temperature exceeding $34^{\circ} \mathrm{C}$ for 7 days during the post-anthesis period of wheat was identified as thermal constraints in realizing potential productivity.

Multiple linear regression models involving grain yield as dependent variable and weather parameters occurring at different phases of growth as independent variables were 
Table 1: Thresholds of maximum and minimum temperatures during different phenological stages of wheat for realization of different yield levels

\begin{tabular}{|c|c|c|c|c|c|c|}
\hline \multirow[t]{2}{*}{ Yield levels $\left(\mathrm{kg} \mathrm{ha}^{-1}\right)$} & \multicolumn{2}{|c|}{ Sowing to tiller initiation } & \multicolumn{2}{|c|}{$50 \%$ flowering to milking } & \multicolumn{2}{|c|}{$50 \%$ flowering to maturity } \\
\hline & $\mathrm{T}_{\max }\left({ }^{\circ} \mathrm{C}\right)$ & $\mathrm{T}_{\min }\left({ }^{\circ} \mathrm{C}\right)$ & $\mathrm{T}_{\max }\left({ }^{\circ} \mathrm{C}\right)$ & $\mathrm{T}_{\min }\left({ }^{\circ} \mathrm{C}\right)$ & $\mathrm{T}_{\max }\left({ }^{\circ} \mathrm{C}\right)$ & $\mathrm{T}_{\min }\left({ }^{\circ} \mathrm{C}\right)$ \\
\hline$<2000$ & 22.6 & 7.6 & 30.2 & 16.8 & 33.1 & 18.0 \\
\hline$>2000$ and $<3000$ & 24.0 & 9.2 & 29.4 & 15.1 & 32.1 & 17.2 \\
\hline$>3000$ and $<4000$ & 22.5 & 9.8 & 26.9 & 13.1 & 30.4 & 15.7 \\
\hline$>4000$ & 23.7 & 11.8 & 24.6 & 11.6 & 29.2 & 14.4 \\
\hline
\end{tabular}

Table 2: Correlation coefficients of the relationships between grain yield and weather parameters during different phenophases of wheat

\begin{tabular}{llll} 
& Sowing to tiller initiation & $50 \%$ flowering to milk & $50 \%$ flowering to maturity \\
\hline $\mathrm{T}_{\text {max }}\left({ }^{\circ} \mathrm{C}\right)$ & 0.09 & $-0.76^{* *}$ & $-0.73^{* *}$ \\
$\mathrm{~T}_{\text {min }}\left({ }^{\circ} \mathrm{C}\right)$ & $0.49^{* *}$ & $-0.76^{* *}$ & $-0.75^{* *}$ \\
$\mathrm{BSH}$ (hour) & $0.33^{*}$ & -0.19 & -0.029 \\
\hline
\end{tabular}

BSH: Bright sunshine hours, *: Significant at $5 \%$ level, **: Significant at $1 \%$ level.

Table 3: Regression equations of grain yield with weather parameters during different pheno-phases of wheat

\begin{tabular}{lll}
\hline Growth phases & Regression equations & Adjusted $\mathrm{R}^{2}$ \\
\hline Sowing to tiller initiation & $\mathrm{Y}=4241.0-181.70 \mathrm{X}_{1}+346.35 \mathrm{X}_{2}$ & $0.541^{*}$ \\
$50 \%$ flowering to milking & $\mathrm{Y}=9859.93-151.31 \mathrm{X}_{1}-173.56 \mathrm{X}_{2}$ & $0.614 * *$ \\
$50 \%$ flowering to maturity & $\mathrm{Y}=11935-89.58 \mathrm{X}_{1}-363.65 \mathrm{X}_{2}$ & $0.571 * *$ \\
\hline
\end{tabular}

$\mathrm{Y}=$ Grain yield of wheat $\left(\mathrm{kg} \mathrm{ha-}-{ }^{1}\right), \mathrm{X}_{1}=$ Maximum temperature $\left({ }^{\circ} \mathrm{C}\right), \mathrm{X}_{2}=$ Minimum temperature $\left({ }^{\circ} \mathrm{C}\right)$.

developed for prediction of grain yield of wheat at different stages of crop growth (Table 3). The coefficient of determination $\left(\mathrm{R}^{2}\right)$ of the models were able to explain 54.1, 61.4 and 57.1 per cent of the total variations in the grain yield by linear functions, involving $\mathrm{T}_{\max }$ and $\mathrm{T}_{\min }$, prevailing during sowing to tillering, $50 \%$ flowering to milk and $50 \%$ flowering to maturity stages, respectively. In terms of values of $\mathrm{R}^{2}$ of different phasic models, maximum and minimum temperatures played most important role in influencing grain yield of wheat during $50 \%$ flowering to milk stage $\left(\mathrm{R}^{2}=0.614^{* *}\right)$, followed by $50 \%$ flowering to maturity $\left(\mathrm{R}^{2}=0.571^{* *}\right)$ and sowing to tiller initiation $\left(\mathrm{R}^{2}=0.541^{* *}\right)$. The results led to understand that $50 \%$ flowering to milk is the most sensitive phase of growth, followed by $50 \%$ flowering to maturity and sowing to tiller initiation to the variations in maximum and minimum temperatures which increased with delay in sowing dates and caused adverse effect upon growth and grain production. Temperature above a threshold value for a few days during anthesis period can significantly reduce yield by affecting subsequent reproductive processes (Wheeler et al., 2000).

\section{Climatic suitability and possibility of early planting of wheat crop}

The results emanated from the wheat-weather relationship revealed that the crop sown early by 15 November would complete its most sensitive flowering phase during 15-20 February, beyond which increase in day temperature above $25{ }^{\circ} \mathrm{C}$ accompanied by dry westerly winds tends to interfere with pollination of wheat crop, thereby adversely affecting the grain setting (Anon, 2009). Hence, if a crop is planted earlier around 15 November, there is higher possibility that the sensitive phases of reproductive and maturity period would escape terminal high temperatures (Fig. 6). To corroborate this fact, plots of average air temperature recorded during $50 \%$ flowering to milk, $50 \%$ flowering to physiological maturity of wheat crop across different dates of planting viz. 15 November, 25 November, 05 December, 15 December and 25 December for five wheat growing seasons (2011-12 to 2015-16) against grain yield demonstrated that with delayed planting, sensitive phases 
of the crop experience higher air temperature, which led to reduction in grain yield (Fig. 6). Pre- and post-anthesis high temperatures and heat had massive impact upon wheat growth, whereas stress reduced photosynthetic efficiency (Wang et al., 2011). Considering grain yield vis-à-vis temperature regimes during flowering to maturity stage, the most viable recommendation emerged from this study for the farmers of the region would be to finish wheat sowing before 25 November. The anthesis-time management by manipulating sowing of crop under different time periods could be an adaptation strategy for optimum yield under changing climate (Richards, 2006). Nathaniel et al. (2012) considered shifting of sowing date as one of the adaptive options under climate change condition.

The results further imply that advancing the sowing of wheat could prove a boon for millions of farmers in the region in escaping terminal heat stress induced by high temperatures and thereby realizing higher yield of wheat. Daily normal maximum, minimum and average air temperature during wheat growing season presented in Fig. 5 shows that there is a tendency of maximum and minimum temperatures in the region to shoot up above $25^{\circ} \mathrm{C}$ and $12^{\circ} \mathrm{C}$, respectively from 20 February onwards surpassing critical thresholds. Critical temperature thresholds identified (Table 1) revealed that during $50 \%$ flowering to milk stage, $\mathrm{T}_{\max }$ and $\mathrm{T}_{\min }$ above $24.6^{\circ} \mathrm{C}$ and $11.6^{\circ} \mathrm{C}$, respectively reduced grain yield below $4000 \mathrm{~kg} \mathrm{ha}^{-1}$. An increase of $\mathrm{T}_{\text {max }}$ from 29.2 to $32.1{ }^{\circ} \mathrm{C}$ during flowering to physiological maturity diminished the grain production drastically. Even under optimum conditions, small variations in temperature influenced the growth and development of barley (Savin and Nicolas, 1996).

\section{CONCLUSIONS}

Crop weather relationship studies in wheat revealed that date of sowing had significant impact on grain yield and by manipulating the sowing date, the crop can be better adapted to a particular thermal environment ensuring its sustainable productivity. Flowering to milk stage was identified to be most sensitive stage for temperature stress in wheat. For achieving higher yield of wheat in this region, $\mathrm{T}_{\min }$ and $\mathrm{T}_{\text {max }}$ should not be greater than $12-13{ }^{\circ} \mathrm{C}$ and $25-$ $26^{\circ} \mathrm{C}$, respectively during $50 \%$ flowering to milk stage. In order to escape terminal heat stress and thereby attaining higher yield, farmers of this region need to finish the sowing of wheat before 25 November. Moreover, the growth phasespecific thresholds of temperature identified through this study could be useful for developing crop-weather calendar of wheat, designing weather-index-based crop insurance products and also for breeding temperature stress-resistant genotypes of wheat for the middle Gangetic plains of India.

\section{REFERENCES}

Anon. (2009). Annual Progress Report, All India Coordinated Research Project on Agrometeorology(Indian Council of Agricultural Research), RAU, Pusa, Bihar, pp. 52.

Bal, S.K., Mukherjee, J., Mallick, K. and Hundal, S.S. (2004). Wheat yield forecasting models for Ludhiana district of Punjab state. J. Agrometeorol. 6(Spl. Issue): 161-165.

Bal, S.K., Bhagat, K.P., Chowdhury, A.R., More, N., Suman, S. and Singh, H. (2018). Managing Photo-thermal Environment for Improving Crop Productivity. In: "Advances in Crop Environment Interaction". (Eds. S.K. Bal et al.). pp.153-179, Springer Nature Singapore Pte Ltd.

Bapuji Rao, B., Chowdary,P.S., Sandeep, V.M., Pramod, V.P. and Rao, V.U.M. (2015). Spatial analysis of the sensitivity of wheat yields to temperature in India. Agric. For. Meteorol., 200:192-202.

Chatrath, R., Mishra, B., Ortiz-Ferrara, G., Singh, S.K. and Joshi, A.K. (2007). Challenges to wheat production in South Asia. Euphytica., 157: 447-456.

DES, (Department of Economics and Statistics, Government of India). (2017). Commodity profile of wheat for January 2017. http://agricoop.nic.in/sites/default/files/ Wheat.pdf.

Draper, N.R. and Smith, H. (1966). Applied regression analysis. John Wiley \& sons, New York, pp.407.

Farooq, M., Bramley, H., Palta, J.A. and Siddique, K.H. (2011). Heat stress in wheat during reproductive and grainfilling phases. Critical Rev. Plant Sci., 30(6): 491-507.

Gomez, K.A. and Gomez,A.A.(1984). Statistical Procedures for Agricultural Research $\left(2^{\text {nd }}\right.$ Edition $) . J o h n$ Wiley \& Sons, New York, pp. 680.

Hays, D.B., Do, J.H., Mason, R.E., Morgan, G. and Finlayson, S.A. (2007). Heat stress induced ethylene production in developing wheat grains induces kernel abortion and increased maturation in a susceptible cultivar. Plant Sci., 172: 1113-1123.

IPCC. (2001). Climate Change: The Scientific Basis. In: (Eds. JT Houghton et al.). p.881. Cambridge University Press, Cambridge, UK.

Joshi,A.K., Mishra,B., Chatrath, R., OrtizFerrara, G. and Singh, R.P. (2007). Wheat improvement in India: Present Status, Emerging Challenges, and Future Prospects. Euphytica, 157: 431-446. 
Landau, S., Mitchell, R.A.C., Barnett, V., Colls, J.J., Craigon, J., Moore, K.L. and Payne, R.W. (1998). Testing winter wheat simulation models predictions against observed UK grain yields. Agric. Forest Meteorol., 89: 85-99.

Lin, W., Ziska, L.H., Namuco, O.S. and Bai, K. (1997). The interaction of high temperature \& elevated $\mathrm{CO} 2$ on photosynthetic acclimation of single leaves of rice in situ. Plant Physiol., 99:178-184.

Lobell, D.B., Ortiz-Monasterio, J.I., Asner, G.P., Matson, P.A., Naylor, R.L and Falcon, W.P. (2005). Analysis of wheat yield and climatic trends in Mexico. Field Crops Res., 94: 250-256.

Lobell, D.B. and Field, C.B. (2007). Global scale climate-crop yield relationships and the impact of recent warming. Environ. Res. Lett., 2: 1-7.

Nahar, K., Ahamed, K.U. and Fujita, M. (2010). Phenological variation and its relation with yield in several wheat (Triticum aestivum L.) cultivars under normal and late sowing mediated heat stress condition. Notulae Scientia Biol., 2: 51-56.

Nathaniel, D.M., James, S.G., Matt, J., Deepak, K.R., Navin, R. and Jonathan, A.F. (2012). Closing yield gaps through nutrient and water management. Nature, 490: 254257.

Ottman, M.J., Kimball, B.A., White, J.W. and Wall, G.W. (2012). Wheat growth response to increased temperature from varied planting dates and supplemental infrared heating. Agron. J., 104: 7-16.

Porter, J.R. and Gawith, M. (1999). Temperatures and the growth and development of wheat: a review. Eur. J. Agron., 10: 23-36.

Prasad, P.V.V., Pisipati, S.R., Ristic, Z., Bukovnik, U. and Fritz, A.K. (2008). Impact of night time temperature on physiology and growth of spring wheat. Crop Sci., 48: 2372-2380.

Richards, R.A. (2006). Physiological traits used in the breeding of new cultivars for water-scarce environments. Agric. Water Manage., 80: 197-211.

Sandhu, S.S., Prabhjyot-Kaur, Tripathi, P., Patel, S.R., Rajender Prasad, Solanki, N.S., Ramesh Kumar, Singh, C.B., Dubey A.P. and Rao, V.U.M. (2016). Effect of intraseasonal temperature on wheat at different locations of India: A study using CERES-Wheat model. $J$. Agrometeorol., 18(2):222-233.

Sattar, A., Kumar, Manish., Khan, S.A. and Pandey, I.B. (2014). Calibration and validation of DSSAT 4.5 model for wheat in North-West Bihar. J. Agrometeorol., 16: 180185.

Sattar, A., Kumar, M., Vijaya Kumar, P. and Khan, S.A. (2017). Crop weather relationship in kharif rice under Northwest Alluvial Plain Zone of Bihar. $J$. Agrometeorol., 19(1):71-74.

Savin, R. and Nicolas, M.E. (1996). Effects of short periods of drought and high temperature on grain growth and starch accumulation of two malting barley cultivars. Aust. J. Plant Physiol., 23: 201 - 210.

Shpiler, L. and Blum, A. (1986). Differential reaction of wheat cultivars to hot environments. Euphytica, 35: 483492.

Tewari, S.K. and Singh, M. (1993). Yielding ability of wheat at different dates of sowing: a temperature development performance. Ind. J. Agron., 38: 204-209.

Vijaya Kumar, P., Rao, V.U.M., Bhavani, O., Dubey, A.P., Sidhu, P.K., Patel, S.R. and Venkateswarlu, B. (2013). Optimizing sowing dates and selection of varieties of wheat through long-term crop and weather analysis, J. Agrometeorol., 15: $67-72$.

Vijaya Kumar, P., Rao, V.U.M., Bhavani, O., Dubey,A.P., Singh, C.B. and Venkateswarlu, B. (2015). Sensitive growth stages and temperature thresholds in wheat (Triticum aestivum L.) for index-based crop insurance in the IndoGangetic Plains of India. J. Agric. Sci., doi:10.1017/ S0021859615000209: 1-13.

You, L., Rosegrant, M.W., Wood, S. and Sun, D. (2009). Impact of growing season temperature on wheat productivity in China. Agric. Meteorol., 149: 1009-1014.

Wang, X., Cai, J., Jiang, D., Liu, F., Dai, T. and Cao, V. (2011). Pre-anthesis high-temperature acclimation alleviates damage to the flag leaf caused by post-anthesis heat stress in wheat. J. Pl. Physiol., 168(6): 585-593.

Wang, J., Wang, E., Yang, X., Zhang, F. and Yin, H. (2012). Increased yield potential of wheat- maize cropping system in the North China Plain by climate change adaptation. Clim. Change, 113: 825-840.

Wheeler, T.R., Batts, G.R., Ellis, R.H., Hadley, P. and Morrison, J.I.L. (1996). Growth and yield of winter wheat (Triticum aestivum) crops in response to $\mathrm{CO}_{2}$ and temperature. $J$. Agric. Sci. Cambridge, 127: 37-48.

Wheeler, T.R., Craufurd, P.Q., Ellis, R.H., Porter, J.R. and Vara Prasad, P.V. (2000). Temperature variability and the annual yield of crops. Agric. Ecosys. Environ., 82: 159 $-167$. 